\title{
Dao Philosophy and Dao Teaching: From the Perspective of Dao De Jing
}

\author{
Dilin Yao ${ }^{1, ~ *, ~ J u n ~ C h e n ~}{ }^{2}$, Bingliang Song ${ }^{1}$ \\ ${ }^{1}$ School of Economics and Management, Shanghai Maritime University, Shanghai, China \\ ${ }^{2}$ SHU-UTS SILC Business School, Shanghai University, Shanghai, China
}

Email address:

meiyiyao@hotmail.com (Dilin Yao), robert_chenj@aliyun.com (Jun Chen), blsong@shmtu.edu.cn (Bingliang Song)

${ }^{*}$ Corresponding author

\section{To cite this article:}

Dilin Yao, Jun Chen, Bingliang Song. Dao Philosophy and Dao Teaching: From the Perspective of Dao De Jing. Education Journal. Vol. 6, No. 5, 2017, pp. 145-151. doi: 10.11648/j.edu.20170605.11

Received: August 10, 2017; Accepted: August 23, 2017; Published: September 22, 2017

\begin{abstract}
Chinese traditional philosophy can provide insights for teacher education. The purpose of this article is to discuss two main aspects of Dao philosophy, Dao teachers' cultivation and Dao teaching behavior, in order to interpret the nature of Dao teaching. This article outlines a conceptual model of Dao teaching consisting of Dao teachers' cultivation based on Laozi's three essentials and Dao teaching behavior based on the nature of water philosophy to guide the teaching performance of teachers. The Dao teaching construction model offers a new perspective for teacher education research and practice. The article concludes with a discussion of the practical value of considering Dao philosophy as an underlying approach to teacher education.
\end{abstract}

Keywords: Dao De Jing, Dao Philosophy, Dao Teaching, Teacher Education

\section{Introduction}

In recent years, there are more interests in eastern philosophy to look for ideas related with education [13]. Chinese traditional Dao philosophy can add a new perspective to contribute to the teacher education research. The purpose of this article is to elaborate Dao teaching based on Dao philosophy, drawing the essential contents related with teacher education from eighty-one chapters of Dao De Jing. All the related chapters in the following sections use mainstream interpretations of Dao De Jing [18], which were translated by the authors. Dao philosophy which arises from the book of Dao De Jing forms the essential basis of this article. The author of Dao De Jing is a great ancient Chinese philosopher Laozi who born approximately 2500 years ago. Dao De Jing consists of two parts Dao Jing and De Jing with five thousand words. Laozi identified intangible Dao as the nature of the universe and all things in the earth. Thus, wisdom for all tangible phenomena in life could be obtained, including the scientific teaching theories and practices from Dao philosophy. The specific concept interpreted in this article is Dao teaching with the purpose to make an essential contribution to knowledge: it outlines a conceptual model of Dao teaching consisting of Dao teachers' cultivation based on Laozi's three essentials and Dao teaching behavior that can help teachers to improve students' performance and support the class based on the nature of water philosophy. This paper has mainly four sections. First, Dao philosophy is introduced. Second, literature in teacher education is presented. Third, the concept of Dao teaching is interpreted and a Dao teaching model is constructed, consisting of Dao teachers' cultivation based on Lao Zi's three essentials and the elements of Dao teaching behavior based on the nature of water philosophy. Finally, the paper concludes with a discussion of the value of considering Dao philosophy in relation to teacher education.

\section{Dao Philosophy}

Dao is mystic and hard to be interpreted explicitly [12]. In the Chapter 1, 21 and 25 of Dao De Jing, Laozi presented that Dao is the origin of the universe. The essence of Dao is intangible, invisible and inexhaustible. Dao is eternal and profound. Dao gives birth to myriad of things and all myriad of things originate from the state of existence (Chapter 6). 
However, the state of existence originates from the state of non-existence (Chapter 40). Chapter 42 presented the principle of creation in Dao. Dao is the origin of all things. Yet Dao is nameless. Forcibly, it is regarded as one. After this oneness is separated into two, there are yin and yang. After the creation of yin and yang, heaven and earth assumed their respective positions naturally. After the creation of two, there is differentiation. With differentiation, there are two extremes. There is a mid-point between the two extremes. This is how two changes into three. Three is assigned as the number that represents creation. From three, numerous fauna and flora are created. All things with forms and images become the myriad of things in the world.

Chapter 51 and 52 indicated that Dao creates all myriad of things and nurtures everything so that they are able to grow and mature. The nourishment and nurturing from Dao is everlasting. Dao is never possessive even though it provides tremendous blessings to everything with nourishment and protection. Dao is never boastful of its strength in accomplishing these great deeds. Indeed, Dao possesses the most profound and ultimate virtue. Dao is the essence. Myriad of things are the manifestation of Dao. Nowadays, people recognize only tangible things instead of Dao. After Dao has been recognized, we need to return to the embrace of Dao. Dao is the universal law [6]. As a result, people must follow the rule of Dao [12,9]. Although the essence of Dao is empty, it creates inexhaustible energy to be used by all myriad of things (Chapter 4). Dao is the foundation to support teaching and education. The following sections would illustrate what is the Dao of teaching and how teachers' cultivation and teaching behavior would follow the Dao philosophy.

\section{Literature in Teacher Education}

Teacher education has attracted a number of attentions and is facing pressures how to improve teacher quality [7, 11]. Cochran-Smith [4] indicated that teacher quality is one of the essential factors in students' improvement and educational development. Teacher education is in a paradox. Teaching looks easy superficially $[8,14]$. However, teaching is difficult.

In many studies of teacher education, the teacher as role model with qualities that students could learn and imitate is generally accepted. As Noddings [15] presented that "Almost all approaches to moral education recognize the importance of modeling. If we would teach the young to be moral persons, we must demonstrate moral behavior for them" (p.168). The teacher is considered to be the important model to form morality of the students aside from academic responsibility. As Althof and Oser [1] stated that "Beyond being good instructors, good teachers know that they are role models, with a responsibility to foster students' social understanding, and a choice to help to facilitate or destroy a willingness to find humane, cooperative, peaceful strategies of interpersonal negotiation and conflict solving" (p.197). The most powerful way of character education to students is the consistent exhibition of good character modeled by teachers [10]. Dao philosophy and Lao Zi's three essentials in Dao De Jing would be a contribution to prepare teacher candidates with the cultivation of moral teacher model.

Many researchers in teacher education emphasized to prepare teacher candidates to develop an ethical knowledge system, enabling them to better understand the ethical considerations which relate with teachers' role model to ensure they would not be badly influenced by poor exemplars in teaching practice. Richardson [16] indicated that "helping teacher education students develop ways of thinking ethically, making judgments, and acting in classroom situations that are thought to be full of ambiguity and dilemmas" (p.186). As Campbell [3] presented that teacher education is to help teacher candidates develop moral and ethical knowledge as the guide to make decisions in the ethical dilemmas they face in their professional practice, which should be considered deeply into the course level. The teacher education need to incorporate moral and character education into the knowledge and skill education. This viewpoint of moral and character development encourages the cultivation of morality and virtue of teachers $[2,10]$. The good virtues of water philosophy in Dao De Jing can be a good perspective to prepare teachers to gain the ethical knowledge and develop good characters and behaviors.

Summarily, Dao philosophy in Dao De Jing helps teacher education to prepare teacher candidates as the moral exemplar and cultivate virtue, character and behavior that is named as Dao teaching which would be illustrated specifically in next section.

\section{The Dao of Teaching}

Based on Dao philosophy, the Dao of teaching is defined as teachers conducting Dao teaching behaviors under Dao teachers' cultivation, guiding the way of teaching, inspiring and nurturing teachers and students in their natural pursuits. Dao teaching includes the sub-dimensions of Dao teachers' cultivation and Dao teaching Behavior (Figure 1). The main philosophical characteristics of Dao teaching in Dao De Jing are explained as follows:

First, Chapter 17 presented that enlightened rulers of the ancient times taught their people without saying many words and handled the country's affairs without any acknowledgement. Naturally, people in the country followed their emperors' directions. Even though the subjects received tremendous blessings from the emperors, they were oblivious of the efforts of their emperors. The Dao of teaching is when teachers teach, students hardly feel the existence of teaching. Students take initiative actions to their own learning.

Second, Chapter 47 indicated that there is an absolute principle in the world which teach people understanding everything without having to step outside of homes. The Dao teaching would teach this Dao principle, aside from the knowledge. As Chapter 48 presented that it is a lifelong benefit to learn Dao. One has to rid himself of the sensual desires and improper thoughts. Hence, he who devotes himself to the Dao will diminish his wrongdoing day by day. In addition, one should also shed the attachments of superficial 
human relationships, as well as fame and wealth. Dao teaching would teach students what to cut.

Finally, Chapter 54 presented that a person's virtue will only be perfected if he diligently cultivates himself. If a virtuous person successfully regulates his family, the community, the country and even the whole world, everyone in the family, the community, the country and even the whole world benefits from his virtue. Let the Dao and virtue be present in teaching, and students will benefit from Dao teaching. Chapter 62 indicated that often times, one only needs to speak a single wonderful sentence in accordance with Dao to gain admiration from others. Noble behavior is behavior in accordance with Dao. An outstanding person is one who maintains a noble behavior. Thus, one purpose of Dao teaching is to educate students with virtues' cultivation and noble behaviors to become an outstanding person.

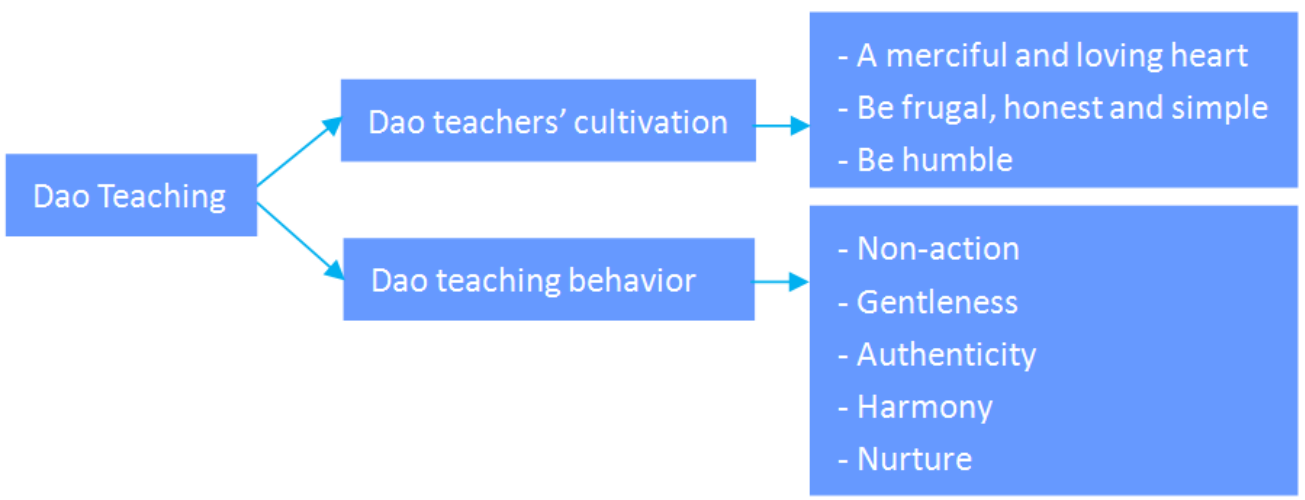

Figure 1. Construction of Dao Teaching Model.

In Summary, Chapter 18 indicated that as technology became more advanced and civilization more developed, human hearts became more conniving and hypocritical. People no longer upheld benevolence, righteousness and morality. Therefore, there were endless incidents of trickery and scams. When the Dao of teaching is forgotten, the students' cleverness and deception increase. Chapter 53 indicated that originally, the path of the great Dao is very smooth and wide. Unfortunately, some greedy people always like to look for shortcuts. Regrettably, those who take shortcuts and forget Dao will only harm themselves in the end. Laozi in Chapter 70 presented that his opinion is very simple and understandable. People are not able to understand and follow because their nature has been deluded. Only a very small number of people are able to truly understand Dao. This is why Laozi referred to Dao as profoundly precious. Teachers need to stay with the Dao of teaching which refers to the cultivation of Dao teachers' virtues and following the Dao teaching behaviors based on Dao philosophy, which will be illustrated further in the following sections.

\section{Dao Teachers' Cultivation - The Three Essentials}

Chapter 41 presented that due to their great foundation and extensive knowledge, sagely people have aspiring goals in life. As soon as they encounter the Dao, they realize that Dao is what they strive to accomplish and they will embrace Dao immediately. When wise teachers hear of the Dao, they quickly begin to embody it, which are called Dao teachers. Chapter 67 identified three essentials regarding cultivating Dao teachers in accordance with Dao philosophy: a merciful and loving heart; be frugal, honest and simple; be humble, which can be applied to Dao teachers' cultivation.

\subsection{A Merciful and Loving Heart}

Chapter 77 presented that the way Dao treats myriad of things is highly disciplined and complimentary in nature. It will use whatever is in surplus to compensate what is lacking. Dao guides those who are in a high position to assist those who are in a low position. Thus, Dao balances all things. Dao teachers should imitate the principle of Dao benefiting all students and offering kind helps to students in need. As Chapter 7 and Chapter 38 presented that a truly virtuous person assists others, placing others ahead of himself, sacrifices and contributes himself without any expectations (Chapter 81). The more teachers assist students, the richer they are. The more they offer their knowledge to students, the greater are their rewards. Nothing can escape from the net of karmic retribution (Chapter 73).

Chapter 58 indicated that people will only be able to enjoy a life of simplicity and stability when a ruler is magnanimous in governing the country. On the other hand, people will become conniving, scheming and restless when the ruler is arrogant and imposes harsh and severe punishments. If the learning environment is managed with repression, the students will resist. The one who substitutes as the wood-cutter in chopping wood will inevitably hurt his own hands (Chapter 74). Trying to control students through punishment is not the purpose of education. Finally, the teachers themselves will get hurt. As Chapter 75 indicated when rules are too harsh and the environment is too controlling, the students will rebel. A country gains the ultimate triumph if it fights in a war to protect its own people with a kind heart (Chapter 69). Even though teachers will punish their students, they should keep a loving heart. Chapter 80 described a simple and harmonious lifestyle with the management of love. If a class is managed 
with teacher's love, the students will enjoy learning, staying at school and love their teachers.

\subsection{Be Frugal, Honest and Simple}

Chapter 13 identified why do people behave apprehensively when they receive praises and insults? It is because people regard praises as supreme honor and insults as low and mean. People are afraid that one day, praises will vanish, just like fame and wealth. People equate insults to the mockery they may receive after they lose their position. Dao teachers should remain detached from fame and success which would keep the teaching position off balance. Chapter 12, 35 and 50 indicated that no one should indulge in enjoyment even though peace and harmony have been restored. Enjoyment is as brief as the passage of a visitor. It does not last forever. Only our true nature, which is the manifestation of Dao, is as eternal as the void. Dao is so plain and simple. Dao teachers should live a frugal and simple life.

Chapter 44 presented that a person will exhaust himself and lose out greatly if he pursues materialistic possession, fame and gains excessively. The more valuable possessions one owns, the greater the chance of inciting jealousy and hatred from others. Personal calamity will ensue. A content person who minimizes his desires will not encounter dangerous disasters. If teachers depend on others for contentment, they will never be content. If their happiness depends on money, they will never be happy with themselves. As Chapter 22 indicated that those who are greedy for materialistic possessions are most deluded. By keeping a fulfilled heart and closely guarded true nature, past saints have become worthy examples of others in the world. The Dao teacher with simple thinking and frugal life style will become a model for their students.

\subsection{Be Humble}

Chapter 32 and Chapter 66 indicated that the reason a vast ocean becomes the ultimate destination of numerous rivers is in the ocean's ability to adapt itself to a place of lowest position. In a lowest position, an ocean is able to accommodate water, whether it is clean or dirty, from numerous rivers. This is why a vast ocean is the ultimate destination of numerous rivers. All water flows into the ocean, because it is lower than streams and lakes. Humility gives the ocean its power. It is most important for the powerful to lead by example the virtue of humility (Chapter 61). Only people with foresight are not arrogant because they understand arrogance is a disease (Chapter 71). When teachers educate students, they should be humble and make their students without the feeling of being oppressed.

Chapter 39 indicated that the foundation of prestige is built upon a lowly and humble position. The foundation of elegance is built upon humility. This is the way in accordance with the will of Dao. Dao teachers should consistently practice humility. Chapter 45 presented that true completeness seems empty, yet it is fully finished. True wisdom seems foolish. A greatly accomplished person, who is also a humble person, may appear to be imperfect in the eyes of an ordinary person. The level that a greatly accomplished person has reached may not look like something that ordinary people want to emulate. However, the functions provided by a greatly accomplished person will not be diminished due to his humility. This is the reason why people respect, support and obey a greatly accomplished person. The Dao teachers would receive respect from their students because of their humility.

Chapter 59 indicated that to get dressed is the first thing one does as soon as he wakes up. It is everyone's habit to get dressed in the morning. It is something we constantly repeat. Our virtue will be very deep if we regard accumulating virtue as necessary as repeatedly getting dressed in the morning. Dao teachers' virtues need to be accumulated day by day. Chapter 33 identified that to be able to defeat others is a sign of one's strength. Only one who is able to overcome himself can be considered the strongest person. If a person is able to overcome his emotions and desires by upholding benevolence and virtue, then that person has conquered everything and attained eternity. Just like the Dao which cannot be taken or given, promoted or defiled, honored or disgraced (Chapter 56). Dao teachers need to overcome their own shortcomings through Dao cultivation constantly. Chapter 11 indicated that clay is shaped into a pot, but it is the emptiness inside that makes the pot useful. Intangible space is the real function. Dao teachers' virtues are a role model for students. It seems nothing to do with the knowledge, but virtues' cultivation is the real use for future personal development. How Dao teachers should behave? Next section would explain further from the viewpoint of water philosophy.

\section{Dao Teaching Behavior - The Water Philosophy}

Chapter 2 presented that have and have not, difficulty and easiness, long and short, high and low, a soft voice and a loud voice, front and back are relative. Everything in the world has opposite. Every student has their own advantages and disadvantages. Dao does not take sides which knows both good and bad (Chapter 5). Dao teachers should embrace all students in their goodness and badness. Chapter 27 indicated that Dao teachers should not reject any student as the philosophy of water. Laozi presented the natural philosophy of water in Chapter 8 . When water flows to a round space, it morphs into a round shape. When water flows to a square space, it morphs into a square shape. In humid weather, it comes down as rain. In sunny weather, it evaporates and rises. Wilhelm and Baynes [17] indicated that "the highest good is just like water" (p.274). How Dao teachers should behave learning from water philosophy? The specifications will be stated as follows:

\subsection{Non-action}

Water's movement follows the course of non-action of Dao. Chapter 37 indicated that Dao adheres to non-action. Due to its attribute of non-action, Dao accomplishes everything. 
Since eons ago, the saints upheld the non-action essence of Dao to govern the world (Chapter 14). If everyone focuses on the non-action aspect of our original nature in governing the world, the world be governed well (Chapter 3). The Dao teacher should teach by non-action and help students to find their gifts. The meaning of Dao non-action teaching is as Javary [5] described it doing "the right thing at the right time" (p. 9), and then let go. The water moves at the right moment. Knowing when to stop is very essential (Chapter 9). Strong wind and torrential rain will not last forever (Chapter 23). A Dao teacher follows the natural process and knows the point to stop. If teachers talk too much, students grow tired and stop listening. If teachers are too strict, the initiative learning of students is lost. Dao teachers need to find appropriate education time for their students.

Chapter 29 presented that the saints will not exaggerate or do anything impractical. Specifically, the saints will not do anything that is superfluous. Dao teachers educate students in their natural state without trying to control them and let them go their own way. Chapter 57 presented that people will maintain propriety as long as the ruler remains humble and tranquil, does not act on impulse. A ruler should never impose excessive, harsh rules and regulations if he intends to provide convenience to the people. This is the only way to bring about prosperity. Dao teachers learn to follow Dao and stop trying to control. The learning environment will manage itself. The more restrictions you give, the less compliant students will be. Chapter 60 indicated that to govern a large country is like frying many little fish. One should not stir too often or the little fish will crumble. People will find it difficult to adapt and greatly troubled if government changes its policy too frequently. A spirit of harmony and auspiciousness can be achieved if leaders in power uphold Dao's attribute of non-action. Dao Teaching is like frying fish. Teachers will spoil teaching by doing too much.

\subsection{Gentleness}

The water is gentle. Chapter 78 indicated that water is the gentlest of all things. Even though water is gentle, it always claims the final victory when it is attacked by anything strong. Water is soft and yielding, yet in its gentleness it overcomes the hard and unyielding. The gentle teacher overcomes the hard students. Gentle is strong. As Chapter 43 presented that the gentlest thing on earth is water. However, even though water is gentle and soft, it penetrates mountains and earth. Only those who appear to be meek and mild can overcome those who appear to be strong and rigid (Chapter 36). The gentlest teachers in the learning environment overcome the hardest things in that environment. Chapter 76 presented that when a person is alive, his body is soft. Only after a person is dead will his body become rigid. It is the same with all myriad of things. When the flowers, grass and trees are alive, they are soft. Only after they are dead will they become rigid. From the above principle, it is true that those who are strong but stubborn are rushing along their path towards death. On the contrary, those who are humble and soft are trekking on the path of eternity. Thus, when a teacher is soft and yielding, she is popular by students.

\subsection{Authenticity}

Water is authentic and stays in true self. Chapter 28 indicated that a saint who is capable of great accomplishments would rather maintain his pure, innocent, and inconspicuous original nature than become a decorated tool with a hypocritical outward appearance. The saints seek liberation of the true self (Chapter 20 and 72). Acting like an innocent child living according to Dao (Chapter 55). The Dao teacher should return to the true self. Chapter 15 presented that if a person can uphold his true nature in cultivation, he will be humble, content and not arrogant or complacent. A person who is not arrogant or complacent will always mindful of bringing benefits to all and will receive eternal life. One must uphold a pure and innocent heart, maintain selflessness without desires, and restore one's purest and most genuine original nature (Chapter 19). If rulers of a country are authentic, everyone's heart will naturally be pure and everyone will live in peace and harmony (Chapter 65). Dao authentic teachers will lead students and class in a peaceful environment.

\subsection{Harmony}

Since water is non-confrontational towards all myriad of things, all myriad of things are therefore non-confrontational towards water. This is the manifestation of harmony. Chapter 30 indicated that everything in the world follows the course of nature. Everything progresses along the stages of development, maturity, old age and ultimately death. The Dao teacher understands that much of the world is out of her control, and that trying to control everything goes against the Dao of teaching. Chapter 31 presented that a noble person with Dao emphasizes the importance of maintaining a calm mind. He will only resort to scheming and killing when there is absolutely no other alternative. Weapons are only used when it is absolutely necessary. Punishment is a tool of discipline, but Dao teachers avoid it. The Dao teacher creates a learning environment with great compassion, a place where self-discipline is the goal. Chapter 26 presented that the saints constantly adhered to their stable and calm true nature. In order to appreciate one's peaceful nature, one must accommodate everything and be tolerant (Chapter 16). Dao teachers need to stay calm and tolerant in the face of conflict.

Chapter 46 identified when Dao is prevalent, the world enjoys peace and harmony where everyone is content. Chapter 49 presented that the mind of a saint is flexible and is able to adjust according to the attitudes and traditions of the people. He never imposes his own ideas onto others nor discriminates against anyone. A saint does not have a heart of discrimination. Even when a saint encounters unkind people or inglorious events, he will still try to inspire them with his virtue of benevolence. To convert an unkind person to be kind again is a saint's virtue of goodness. Dao nourishes all myriad of things indiscriminately (Chapter 79). Dao teachers do not impose their will upon others. They are good to students who are good and not good. They trust students who are trustworthy and not 
trustworthy. Chapter 68 indicated that since this official is considerate of his subordinates and cares for them sincerely, he is completely accepted and supported by his subordinates. This is rooted cause to construct harmonious learning environment. The Dao teacher embraces the value of cooperation and collaboration.

\subsection{Nurture}

Chapter 34 presented that the energy as manifested to the world by the great Dao is plentiful. Myriad of things in the world rely on the great Dao for their survival. The great Dao does not shy away from its responsibility. In addition, the great Dao will not seek merits, fame or benefits in nourishing everything. It does not claim to be the master of the myriad of things in the world. The great Dao is without desires and does not claim any credits. It appears to be infinitesimal. It does not claim to be the master even though it created all myriad of things. As Chapter 10 indicated that Dao is never possessive, even though it gives rise to all myriad of things and provide for their nourishments. Dao upholds everything is considered to the true meaning of greatness. The Dao teacher does not possess students, but serves them and teaches in a nurturing way without control.

Begin with successfully tackling trivial matters and then progress to accomplish significant matters (Chapter 63). As Chapter 64 indicated that even a big tree that takes two people to encircle begins with a small seed. To embark on a journey of a thousand miles, one must begin with the very first step. Although you try to move ahead, you will not get far if you do not take things one step at a time (Chapter 24). The Dao teacher should be as industrious at the end as at the beginning to conduct Dao teaching behaviors step by step.

\section{Conclusion: The Value of Considering Dao Philosophy on Teacher Education}

This article constructs Dao teaching from the perspective of Dao philosophy with a conceptual model: it consists of Dao teachers' cultivation based on Lao Zi's three essentials and Dao teaching behavior based on the nature of water philosophy. Dao teaching offers a new perspective for teacher education research and help researchers and teachers better comprehend teaching from Dao philosophy. The value for this research is to consider Dao philosophy on teacher education. On the one hand, Dao as the intangible origin of the universe provides philosophical instructions to assist people finding the sense of belongings in the area of uncertainty, volatility, change and ambiguity. Teachers need to return to the origin of the universal rule to rethink about education and teaching. On the other hand, as natural Dao lies in human being, integrating humanistic concern of recognizing and respecting human Dao nature in teachers and students with education research is required. The original texts in Dao De Jing eighty-one chapters are used to present teachers with specific cultivating rules of teachers' virtues and Dao teaching behaviors. Through the way of Dao cultivation, it is helpful to improve teachers' virtues and behaviors continually and stay synchronized with the natural Dao in students and class. This article explores to combine eastern wisdom and philosophy with contemporary education knowledge. Laozi left Dao De Jing in the world with a merciful heart. The future study may further develop specific Dao approach to guide teaching theory and practice.

\section{Acknowledgements}

This research is sponsored by the project of Shanghai Maritime University Core Course Construction of Graduate Students. Project Number: Master (YZ) 2017001.

\section{References}

[1] Althof, W. and Oser, F. (1993), "EDITORIAL Professional morality: Ethical dimensions of teaching", Journal of Moral Education, Vol. 22 No. 3, pp. 197-200.

[2] Berkowitz, M. and Bier, M. (2005), What works in character education? A research driven guide for educators, Character Education Partnership (CEP), Washington DC.

[3] Campbell, E. (2011), "Teacher education as a missed opportunity in the professional preparation of ethical practitioners", in Bondi, L., Carr, D., Clark, C. and Clegg, C. (Eds.), Towards professional wisdom: Practical deliberation in the "people professions", Ashgate Publishing Ltd., Farnham, UK, pp. 81-93.

[4] Cochran-Smith, M. (2004), "Taking Stock in 2004: Teacher Education in Dangerous Times", Journal of Teacher Education, Vol. 55 No. 1, pp. 3-7.

[5] Javary, C. (1997), Understanding the I Ching, Shambhala, Boston, MA and London.

[6] Jing, R. and Van de Ven, A. H. (2014), "A Yin-Yang Model of Organizational Change: The Case of Chengdu Bus Group", Management and Organization Review, Vol. 10 No. 1, pp. $29-54$

[7] Kosnik, C., Miyata, C., Cleovoulou, Y., Fletcher, T. and Menna, L. (2015), "The education of teacher educators", in Falkenberg, T. (Ed.), Handbook of Canadian research in initial teacher education, Canadian Association of Teacher Education, Ottawa, ON, pp. 207-224.

[8] Labaree, D. F. (2005), "Life on the margins", Journal of Teacher Education, Vol. 56 No. 3, pp. 186-191.

[9] Lee, Y. T., Han, A., Byron, T. K. and Fan, H. X. (2008), "Daoist leadership: Theory and application", in Chen, C. C. and Lee, Y. T. (Eds.), Leadership and management in China: Philosophies, theories, and practices, Cambridge University Press, Cambridge, pp. 83-107.

[10] Lickona, T. (1991), Educating for character: How our schools can teach respect and responsibility, Bantam, New York.

[11] Loughran, J. J. (2015), "Thinking about teaching as sophisticated business", in Garbett, D. and Ovens, A. (Eds.), Teaching for tomorrow today, Edify, Auckland, New Zealand, pp. 5-8.

[12] Ma, L. and Tsui, A. S. (2015), "Traditional Chinese philosophies and contemporary leadership", The Leadership Quarterly, Vol. 26 No. 1, pp. 13-24. 
[13] Mackinnon, A. (1996), "Learning to teach at the elbows: The Dao of teaching", Teaching and Teacher Education, Vol. 12 No. 6, pp. 653-664.

[14] Martin, A. K. and Russell, T. (2009), "Seeing teaching as a discipline in the context of preservice teacher education: Insights, confounding issues, and fundamental questions", Teachers and Teaching: Theory and Practice, Vol. 15 No. 2, pp 319-331.

[15] Noddings, N. (2008), "Caring and moral education", in Nucci, L. P. and Narvaez, D. (Eds.), Handbook of moral and character education, Routledge, New York, pp. 161-174.
[16] Richardson, V. (2013), "Teaching moral teaching in teacher education", in Sanger, M. and Osguthorpe, R. (Eds.), The moral work of teaching and teacher education. Preparing and supporting practitioners, Teachers College Press, New York/London, pp. 183-194.

[17] Wilhelm, R. and Baynes, C. F. trans. (1967), I Ching or book of changes (3rd ed.), Princeton University Press, Princeton, NJ.

[18] Yao, D. and Gan, S. (2013), Dao De Jing and Leadership, Economic management press, Beijing. 